Bangladesh J. Plant Taxon. 24(1): 83-89, 2017 (June)

(C) 2017 Bangladesh Association of Plant Taxonomists

\title{
THREE LICHEN TAXA NEW FOR TURKEY
}

\author{
KENAN YAZICI ${ }^{1}$ AND ANDRÉ Aptroot ${ }^{2}$ \\ Biology Department, Faculty of Science, Karadeniz Technical University, \\ 61080, Trabzon, Turkey
}

Keywords: Ascolichen, Lecanoraceae, Hymenchiaaceae; Verrucariaceae.

\begin{abstract}
Three lichen taxa viz. - Aspicilia asiatica (H. Magn.) Yoshim., Lecanora subcarnea (Sw.) Ach. var. soralifera H. Magn., and Thelidium minutulum Körb. were identified as new to Turkey as a result of a lichenological survey in the Bitlis and Muş regions Turkey. In addition, Lecanora subcarnea var. soralifera is also new to Asia. A detail taxonomic account, notes on known distribution, substrates, and chemistry under each taxon and comparisons with morphologically similar taxa are furnished under each taxon.
\end{abstract}

\section{Introduction}

Recently, a lot of lichen taxa have been recorded for Turkey since the surveys about lichen flora are poor (Aptroot and Yazici, 2012; Arslan et al., 2011; Yazici et al., 2010a, b, c, 2011a, b, 2012, 2013; Karagöz and Aslan, 2012; Karagöz et al,. 2011; Kinalioğlu and Aptroo, 2011; Osyczka et al., 2011) but more surveys are still needed of unexplored regions in the country.

Aspicilia A. Massal (Hymeneliaceae) contains approximately 230 species (Nordin et al., 2010). Lecanora Ach. (Lecanoraceae) comprises about than 600 species (McCarth and Mallett, 2004), while Thelidium A. Massal (Verrucaraceae) has about 100 lichen taxa (Orange, 1991). From Turkey 42 taxa of Aspicilia, 105 taxa of Lecanora, and 4 taxa of Thelidium have thus far been reported. Of approximately 1650 lichen taxa that have been recorded for the country only 6 lichenized fungi have been reported from Muş Province (Yazici and Aslan, 2016a,b). On the other hand, 31 lichen species were noted from Bitlis region (Çobanoğlu, 2005; Çobanoğlu and Yavuz, 2007; Vondrak et al., 2012). The present study aims at exploring the lichens in the regions of Muş and Bitlis, eastern Turkey. We report here three lichen taxa which are new records for Turkey and Asia.

\section{Materials and Methods}

The present study is based on collections from the Bitlis and Muş regions made in 2015-2016. Air-dried samples were examined with a Nikon SMZ1500 stereomicroscope and a Nikon Eclipse 80i compound light microscope. Relevant keys were consulted (Dickhäuser et al., 1995; Ceynowa-Giełdon and Adamska, 2014; Orange, 2008; Thüs and Nascimbene, 2008; Poelt and Wirth, 1968; Poelt and Vězda, 1981) for the identifications. Vouchers are stored in the Herbarium of the Biology Department, Karadeniz Technical University, Trabzon, Turkey (KTUB). The diagnosis are based on Turkish specimens.

\section{Study area}

Muş: Center, mostly formed by vast areas of meadow and steppe, and high mountains, are mountainous by Quercus L. communities locally and Salix L. trees are rarely seen in some areas in this region (Baytop and Denizci, 1963). Muş region has a climate characterized by very cold and

\footnotetext{
${ }^{1}$ Corresponding author. Email: kcagri_1997@yahoo.com

${ }^{2}$ ABL Herbarium G.v.d.Veenstraat 107 NL-3762 XK Soest, The Netherlands.

DOI: http://dx.doi.org/10.3329/bjpt.v24i1.33035
} 
very snowy winters, and hot, dry and short summers, with temperatures ranging from -29 to $41.6^{\circ} \mathrm{C}$. Annual rainfall ranges from $350-1000 \mathrm{~mm}$ and the average humidity is $60.3 \%$ (Akman, 1999).

Bitlis region (Tatvan: Nemrut mountain and Adilcevaz) are mountainous with vast open areas, large plain and sometimes Quercus, Populus and Salix trees are seen in some places. Nemrut mountain is a second large extinct crater of the World. There is a lake, many rocks and trees such as Quercus and Populus (Baytop and Denizci, 1963). Thence crustose and foliose lichens are predominantly seen. Collecting localities are well-lit, windswept, treeless areas with gently sloping terrain containing streams, grass, and calcareous and siliceous rocks. The climate is characterized by very cold snowy winters and short hot dry short summers, with a temperature range of $-21.3^{\circ} \mathrm{C}$ to $37^{\circ} \mathrm{C}$, a mean annual rainfall is around $822.9 \mathrm{~mm}$, and mean annual humidity of $61 \%$ (Akman, 1999).

\section{Results}

Aspicilia asiatica (H. Magn.) Yoshim., Nov.Sist. Niz. Rast. 9: 286 (1972).

(Fig. 1).

Thallus crustose, up to $5 \mathrm{~cm}$ diam, \pm cycloid or \pm elliptic, gray, gray-beige, with deep cracked, and areolate; areoles uneven, blistered, corrugated, areolae up to $800 \mu \mathrm{m}$ diam; lobes thin and narrow towards the ends, \pm contiguous, or with light space, sometimes \pm partly overlapping, rarely dichotomic, about $165 \mu \mathrm{m}$, bulky, lobe tips black-brown as if burned. Apothecia up to 1.25 $\mathrm{mm}$ diam, regular or sometimes irregular and with depressed proper margin, aggregated mostly in the middle, scarce towards the lobes, constricted at the base, one per even fertile areol; thallin exciple more or less distinct, thick, $125 \mu \mathrm{m}$ diam, gray, concolorous with the thallus, large; disc concav, pruinose, dark red or dark brown-black, to $900 \mu \mathrm{m}$ diam; epihymenium yellow-brown; hypothecium 50-60 $\mu \mathrm{m}$, yellow brown-gray; hymenium 90-100 $\mu \mathrm{m}$; paraphyses contiguous, apices subglobe, upper part filiform. asci 8-spored, clavate, 65-75 $\times 18-20 \mu \mathrm{m}$; ascospores $17 \times 10$ $\mu \mathrm{m}$, more or less ellipsoid Thallus and medulla $\mathrm{K}-, \mathrm{C}-, \mathrm{KC}-, \mathrm{P}-$, under upper cortex $\mathrm{K}$ more or less yellow-orange.

A detailed description is provided by Oxner (1972).

Aspicilia asiatica grows on calcareous rocks. Previously known from Austria, Afghanistan, Altai-Sayan, China, Mongolia, Tajikistan, Kazakhstan, Kyrgyzstan (Poelt and Wirth, 1968; Abbas et al., 2001; Bredkina and Makarova, 2005; Sedelnikova, 2013). New to Turkey.

Specimen examined: Turkey. Muş: Center, between Üçevler and Muş mainroad, roadside, $38^{\circ} 40^{\prime} 49.85^{\prime \prime} \mathrm{N} 41^{\circ} 25^{\prime} 30.87^{\prime \prime} \mathrm{E}, 2585 \mathrm{~m}$, on calcareous rock, 29.05.2015, leg. K.Yazici. (KTUB2452).

Accompanying species were: Aspicilia cinerea (L. Körb.), Acarospora fuscat (Nyl.) Th. Fr., Acarospora impressula Th. Fr. var. hospitans (H. Magn.) Clauzade \& Cl. Roux, Candelariella vitelline (Hoffm.) Müll..Arg., Immersaria athroocarpa (Ach.) Rambold \& Pietschm., Protoparmeliopsis muralis (Schreb.) M. Choisy, Rhizocarpon geographicum (L.) DC., Rhizoplaca melanophthalma (DC.) Räsänen, Rinodina milvina (Wahlenb.) Th. Fr. and Xanthoria elegans (Link) Th. Fr.

Lecanora subcarnea (Sw.) Ach. var. soralifera H. Magn., Bot. Notiser: 433 (1932).

(Fig. 2).

Thallus crustose up to $5 \mathrm{~cm}$ diam, thick, more or less gray, grayish or yellowish white, epruinose, deeply cracked, areolate; areola blistered, more or less verrucose, surface uneven, margins indistinct. Apothecia up to $1.25 \mathrm{~mm}$ diam.; disc light red-brown, light brown or redbrown, slightly pruinose, slightly concave, $\mathrm{P}+$ orange-red, C-; soralia $0.5-0.7 \mathrm{~mm}$, blue-grey, \pm 
hemisphaerical, occurring on areola, side of apothecia, also on exciple and disc hymenium 90-95 $\mu \mathrm{m}$ high, yellow, yellow-gray, hyaline, clear; paraphyses with thickened upper cells; epihymenium greenish gray-brown; hypothecium hyaline, $150-190 \mu \mathrm{m}$, not oil droplets thallin exciple concolous with the thallus, smooth, entire, prominent (Fig. 2a); asci clavate, 8-spored, 40-45 $\times 8$-10 $\mu \mathrm{m}$; ascospores simple, hyaline, ellipsoid, 9-15 $\times 6-8 \mu \mathrm{m}$ (Fig. 2c).Thallus $\mathrm{K}-$ or slightly yellowbrown, C-, KC-, P + orange-red. Medulla K-, C-, KC, P-. Disc P+ orange-red. Soralia spot tests are negative.
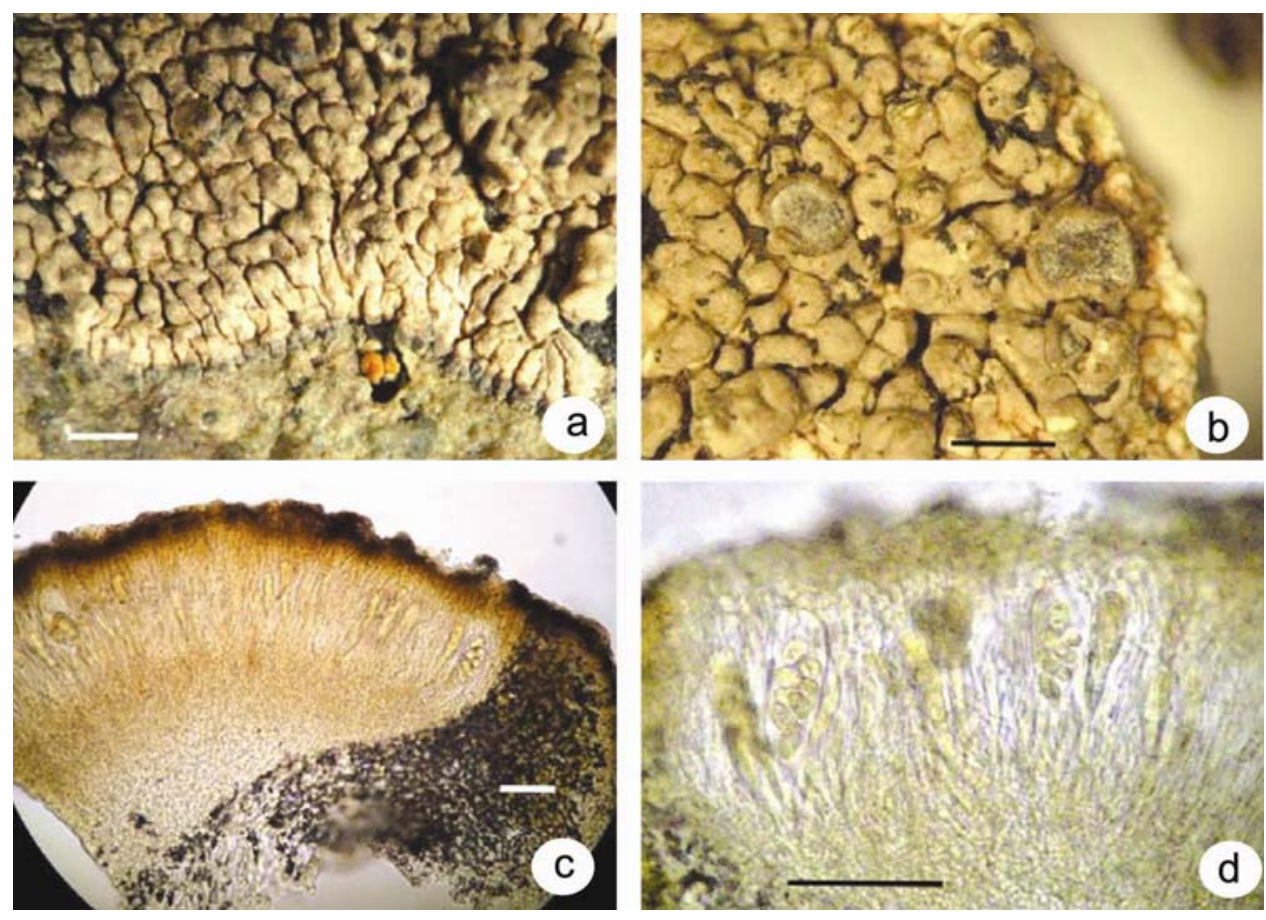

Fig. 1. Aspicilia asiatica, a). Thallus with lobes. Scale $=1 \mathrm{~mm}, \mathrm{~b}$ ). Apothecia with pruinose disc. Scale $=1$ $\mathrm{mm}$, c). Section through apothecium with hymenium, epihymenium, hypothecium, ascus and ascospores. Scale $=50 \mu \mathrm{m}, \mathrm{d})$. Section of apothecium with hymeniıum, ascus and ascospores. Scale $=$ $50 \mu \mathrm{m}$.

Lecanora subcarnea var. soralifera is a mild-temperate to Mediterranean species, mostly growing on calcareous rock, sometimes on walls. Previously known from Austria, Germany, Sweden, Norway, North America (Berger and Priemetzhofer, 2014; Dickhäuser et al.,1995; Eichler et al., 2010). New to Turkey and Asia.

A detailed descriptions are provided by Dickhäuser et al., (1995), Poelt and Vězda, (1981).

Specimen examined: Turkey, Bitlis: Tatvan, Nemrut mountain, $38^{\circ} 36^{\prime} 08.60^{\prime \prime} \mathrm{N} 42^{\circ} 15^{\prime}$ 35.18"E, $2360 \mathrm{~m}$, on calcareous rock, 29.06.2016, leg. K.Yazici. (KTUB-2458).

Thelidium minutulum Körb., Parerga lichenol. (Breslau) 4: 351 (1863).

(Fig. 3).

Thallus crustose, epilithic, thin to moderately thick 50-100 $\mu \mathrm{m}$, continuous, grey, partly greybrown, margin indistinct, up to $5 \mathrm{~cm}$ diam, lightly cracked, uneven, rough, corrugated, granular or 
rimose, also cracked surroundig perithecia; perithecia small, about 150-325 $\mu \mathrm{m}$ diam., $320 \mu \mathrm{m}$ immersed in the thallus, $160 \mu \mathrm{m}$ on the thallus, or $0.5 \mathrm{~mm}$ immersed $0.35 \mathrm{~mm}$ on the thallus, more or less globose to ovate, basal part bounded by algae layer; periphyses present; involucrellum absent or very thin; exciple dark-brown to black, about 100-180 $\mu \mathrm{m}$ diam; asci 8-spored, more or less clavate, $85-90 \times 21-23 \mu \mathrm{m}$; ascospores colourless, ellipsoid, 17-21 $\times 6-8 \mu \mathrm{m}, 2$-celled (Fig. $3 d)$. All spot tests are negative.

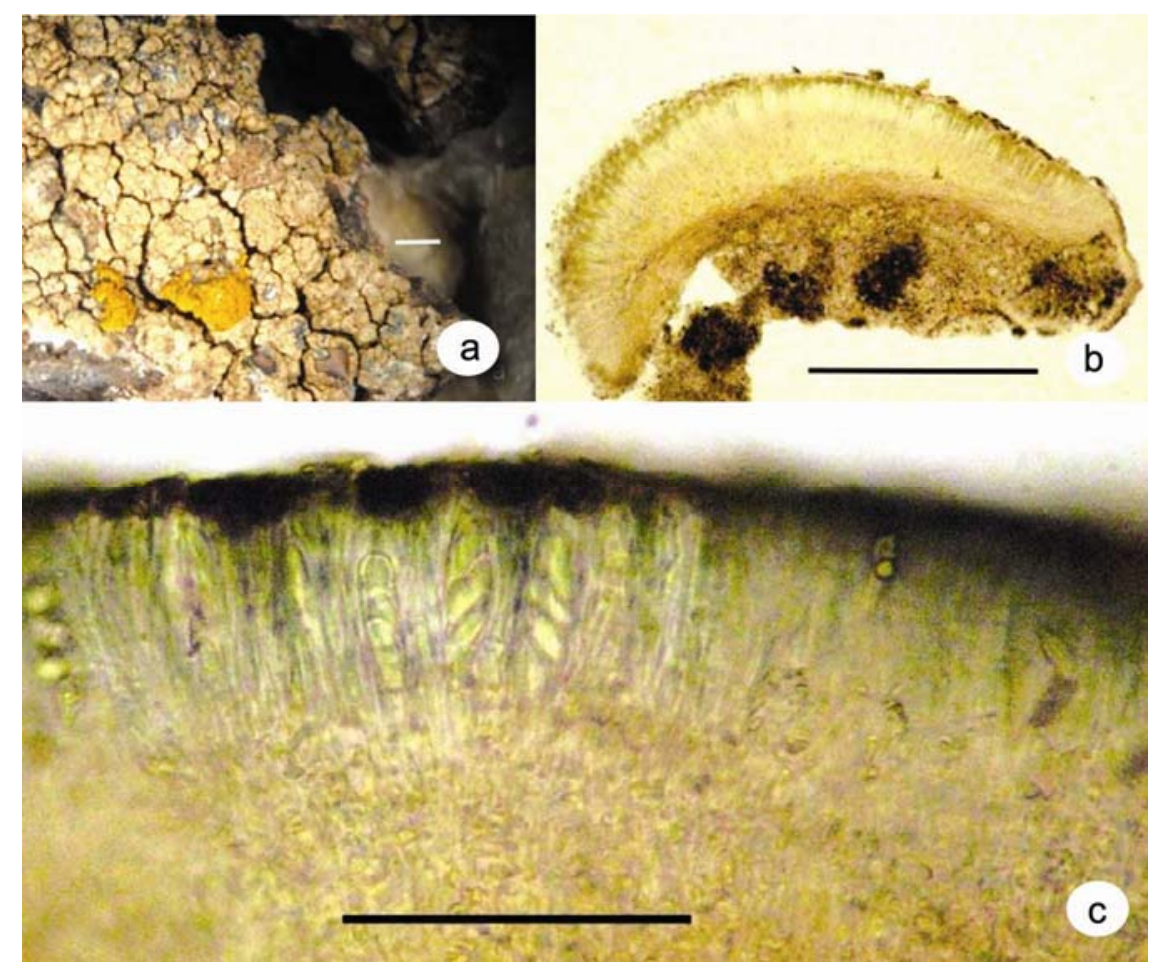

Fig. 2. Lecanora subcarnea var. soralifera, a). Thallus with apothecia and blue-gray soralia. Scale $=1 \mathrm{~mm}$,

b). Cross-section of apothecium with hymenium, epihymenium, hypothecium. Scale $=500 \mu \mathrm{m}, \mathrm{c}$ ).

Section of apothecium with hymenium, ascus and ascospores. Scale $=500 \mu \mathrm{m}$.

A detailed description is provided by Orange (2008).

Thelidium minutulum is a widespread, cool-temperate to arctic-alpine, circumpolar lichen, occuring on calcareous or siliceous rocks, metal-rich, old walls, often vertical faces, limestones, rarely on soil, sterile and grows on steeply inclined faces (Ceynowa-Giełdon and Adamska, 2014; Adamska, 2010; 2012; Ceynowa-Giełdon, 2001). It is known from throughout the Europe. Asia (Taiwan) and North America, (Freire et al., 1999; Thüs and Nascimbene, 2008; Redchenko et al., 2010; Vondrák et al., 2010; Coste ,2011; Pykälä et. al., 2012; Toetenel et al., 2012; CeynowaGiełdon and Adamska, 2014). New to Turkey.

Specimen examined: Turkey, Bitlis: Adilcevaz, Karşıyaka village, surrounding Sodalı Lake, $38^{\circ} 49^{\prime} 26.29^{\prime \prime} \mathrm{N} 42^{\circ} 57^{\prime} 16.60^{\prime \prime} \mathrm{E}, 1712 \mathrm{~m}$, on calcareous rock, 17.07.2016, leg. K.Yazici (KTUB2460).

Notes: Some members of Thelidium minutulum can be confused with Thelidium rehmii Zschacke, but the thallus in T. minutulum is more granular than that of T. rehmii. The photobionts 
in T. minutulum are in small aggregated groups, while those of T. rehmii distributed irregularly in the thallus. Habitat of these two speceis are Also different (Ceynowa-Giełdon, 2001). Moreover this species is morphologically confused with Verrucaria bryoctona (Th. Fr.) Orange. However $T$. Minutulum can be distinguished from $V$. bryoctona in having 2-celled ascospores and structure of excipulum (Aslan and Yazici, 2013). Accompanying species was Verrucaria nigrescens Pers.

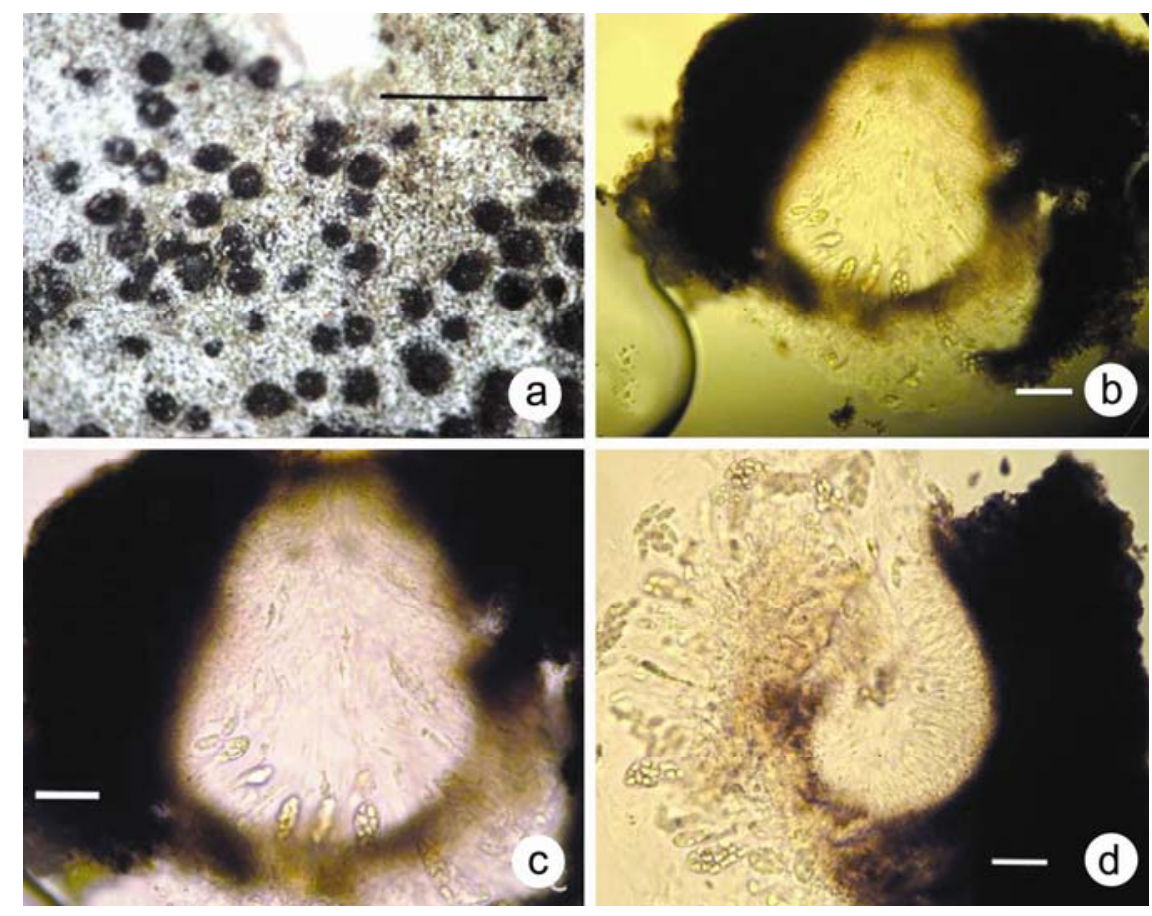

Fig. 3. Thelidium minutulum, a). Thallus with perithecia, habitus. Scale $=1 \mathrm{~mm}$. b). Perithecium covered by algae in small group, periphyses, indistinct brown wall of perthecium, ascus and ascospores. Scale $=50$ $\mu \mathrm{m}, \mathrm{c})$. Section through perithecium coverd by algae, ligth distict brown wall of perithecium, exciple, periphyces, ascus and ascospores. Scale $=50 \mu \mathrm{m}$, d.Section of perithecium with periphyses, ascus and ascospores. Scale $=50 \mu \mathrm{m}$.

\section{Acknowledgements}

This study was supported by TUBITAK (Project 114Z892).

\section{References}

Abbas, A., Mijit, H., Tumur, A. and Jinong, W. 2001. A Checklist of the lichens of Xinjiang, China. Harvard Papers in Botany 5 (2): 359-370.

Adamska, E. 2010. Biota of lichens on the Zadroże Dune and its immediate surroundings, Ecological Questions 12: 51-28.

Adamska, E. 2012. Protected and threatened lichens in the city of Torun. In Lipnicki, L. (Ed.) Lichens Protection-Protected Lichen Species, Sonar Literacki, Gorzów Wielkopolski, pp. 313-323.

Akman, Y. 1999. Climate and bioclimate (The methods of bioclimate and climate types of Turkey). $1^{\text {st }}$ Edn., Kariyer Matbaacılık Ltd., Şti, Ankara. 350 pp. 
Aptroot, A. and Yazıc1, K. 2012. A new Placopyrenium (Verrucariaceae) from Turkey. The Lichenologist 44: 739-741.

Arslan, B., Öztürk, S. and Oran, S. 2011. Lecanora, Phaeophyscia and Rinodina species new to Turkey. Mycotaxon 116: 49-52.

Aslan, A. and Yazici, K. 2013. New Lecanora, Lecidea, Melaspilea, Placynhium, and Verrucaria records for Turkey and Asia. Mycotaxon 123: 321-326.

Baytop, A. and Denizci, R. 1963. Türkiye'nin Flora ve Vejetasyonuna Genel Bir Bakış. Ege Üniv. Fen Fak. Monografiler Ser. 1, Ege Üniv. Mat., İzmir. 43 p.

Berger, F. and Priemetzhofer, F. 2014. Erläuterungen und Erstnachweise von Flechten in Oberösterreich, sowie weitere erwähnenswerte Beobachtungen. 1. Update des Flechtenatlas. Stapfia 101: 53-65.

Bredkina, L .I. and Makarova, I.I. 2005. Checklist of lichens of the central Tian Shan (Kyrgyzstan). Academia Scientarium Rossica 39: 199-218.

Ceynowa-Giełdon, M 2001. Kalcyfilne porosty naziemne na Kujawach (Calciphilous terricolous lichens in Kujawy), Wydawnictwo Uniwersytetu Mikołaja Kopernika, Toruń.

Ceynowa-Giełdon, M., Adamska, E. 2014. Notes on the genus Thelidium (Verrucariaceae, lichenized Ascomycota) in the Kujawy region (north-central Poland). Ecological Questions 19: 25-33.

Coste, C. 2011. Aperçu de la flore et de la végétation lichéniques de la réserve biologique intégrale du cirque de Madasse (Forêt domaniale du causse Noir, Aveyron). Bull. Soc. Hist. Nat. Toulouse,pp. 1-25.

Çobanoğlu, G. 2005. Lichen collection in the Herbarium of the University of Istanbul (ISTF). Turkish J. Bot. 29: 69-74.

Çobanoğlu, G.and Yavuz, M. 2007. Muzeul Oltenici Craiova. Oltenia. Studii şi comunicări. Ştiintele Naturii. Tom 23: 23-26.

Dickhäuser, A., Lumbsch, H.T. and Feige, G.B. 1995. A synopsis of the Lecanora subcarnea group. Mycotaxon 56: 303-328.

Eichler, $\mathrm{M}$ and Cezanne $\mathrm{R}$ and Teuber, $\mathrm{D}$ 2010. Ergänzungen zur Liste der Flechten und flechtenbewohnenden Pilze Hessens. Zweite Folge Botanik und Naturschutz in Hessen 23: 89-110.

Freire, M., Dopaza, M.F. and Molares, A.G. 1999. Flora liquenica saxicola y arenícola de la Península de o Grove (Pontevedra, NW de España. Acta Botanica Malacitana 24: 13-25.

Karagöz, Y. and Aslan, A. 2012. Floristic lichen records from Kemaliye District (Erzincan) and Van Province. Turkish J. Bot. 36: 558-565.

Karagöz, Y., Aslan, A., Yazıc1, K. and Aptroot, A. 2011. Diplotomma, Lecanora, and Xanthoria lichen species new to Turkey. Mycotaxon 115: 115-119.

Kinalioğlu, K. and Aptroot, A. 2011. Carbonea, Gregorella, Porpidia, Protomicarea, Rinodina, Solenopsora, and Thelenella lichen species new to Turkey. Mycotaxon 115: 125-129.

McCarth, P.M. and Mallett, K. 2004. Flora of Australia. CSIRO Publishing Vol. 56. A. Lichens 4, Canberra.

Nordin, A., Savić, S. and Leif Tibell, L. 2010. Phylogeny and taxonomy of Aspicilia and Megasporaceae. Mycologia 102(6): 1339-1349.

Orange, A. 1991. Thelidium pluvium (Verrucariaceae), a new lichenized species from north-west Europe, Lichenologist 23: 99-106

Orange, A. 2008. British Pyrenocarpous Lichens. 69 pp. Distributed by the author.

Osyczka, P., Yazici, K. and Aslan, A. 2011. Note on Cladonia species (lichenized Ascomycota) from Ardahan Province (Turkey). Acta Societatis Botanicorum Poloniae 80: 59-62.

Oxner, A.N. 1972. Conbinationes taxonomicae ac nomina specierum Aspiciliae novae. Novosti Sistematiki Nizshikh Rastenii 9: 286-292

Poelt, J and Wirth, V. 1968. Flechten aus dem Nordöstlichen Afghanistan. Mitt, Bot. München Band 7: 219261.

Poelt, J. and Vězda, A. 1981. Bestimmungsschlüssel europäischer Flechten Ergänzungsheft II. J Cramer, Vaduz. 390 p. 
Pykälä, J., Stepanchikova, I.S., Himelbrant, D.E., Kuznetsova, E.S. and Alexeeva, N.M. 2012. The lichen genera Thelidium and Verrucaria in the Leningrad Region (Russia). Folia Cryptog. Estonica Fasc. 49: 45-57.

Redchenko, O. and Košnar, J. and Gloser, J. 2010. A contribution to lichen biota of the central part of Spitsbergen, Svalbard Archipelago. Polish Polar Research 31(2): 159-168.

Sedelnikova, N.V. 2013. Species diversity of lichen biota of the Altai-Sayan ecological region Растительный мир Азиатской России 2(12c): 12-54

Thüs, H. and Nascimbene J. 2008. Contributions toward a new taxonomy of Central European freshwater species of the lichen genus Thelidium (Verrucariales, Ascomycota). The Lichenologist 40(6): 499-521.

Toetenel, H., Aptroot, A. and Sparrius, L. 2012. De licheenflora van de Kop van Schouwen: een vergelijking over vier decennia. Buxbaumiella 93: 6-21.

Vondrák, J., Halda, J.P., Meliček, J. and Müller, A. 2010. Lichens recorded during the Spring bryolichenogical meeting in Chriby Mts (Czech Republic). Bryonora 45: 36-42.

Vondrák, J., Halici, M.G., Kocakaya, M. and Ondrakova, O.V. 2012. Teloschistaceae (lichenized Ascomycetes) in Turkey. 1. Some records from Turkey. Nova Hedwigia 94: 385-396.

Yazici, K., Aptroot, A., Aslan, A., Etayo, Spier, J. and Karagöz, Y. 2010a. Lichenized and lichenicolous fungi from nine different areas in Turkey. Mycotaxon 111: 113-116.

Yazici, K., Aptroot, A. and Aslan, A. 2010b. Three lichenized fungi new to Turkey and the Middle East. Mycotaxon 111: 127-130.

Yazici, K., Elix, J.A. and Aslan, A. 2010c. Some parmelioid lichens new to Turkey and Asia. Mycotaxon 111: 489-494.

Yazici, K., Aptroot, A., Aslan, A., Vitikainen, O. and Piercey-Normore, M.D. 2011a. Lichen biota of Ardahan province (Turkey). Mycotaxon 116: 480.

Yazici, K., Aptroot, A. and Aslan, A. 2011b. Lecanora wrightiana and Rhizocarpon inimicum, rare lichens new to Turkey and Middle East. Mycotaxon 117: 145-148.

Yazici, K., Aptroot, A. and Aslan, A. 2012. Candelariella, Ochrolechia, Physcia, and Xanthoria species new to Turkey. Mycotaxon 119: 149-156.

Yazici, K., Aslan A. and Aptroot, A. 2013. New lichen records from Turkey. Bangladesh J. Plant Taxon. 20(2): 207-211.

Yazici, K. and Aptroot, A. 2015. Buellia, Lempholemma, and Thelidium species new for Turkey and Asia. Mycotaxon 130: 701-706.

Yazici, K. and Aslan, A. 2016a. Aspicilia, Lobothallia, and Rhizocarpon species new for Turkey and Asia. Mycotaxon 131: 227-233.

Yazici, K. And Aslan A 2016b. Merismatium, Porpidia and Protoparmelia spp. new for Turkey and Asia. Mycotaxon 131: 337-343.

(Manuscript received on 4 November 2016; revised on 25 March 2017) 